\title{
EEN DAJAKSCH FEEST
}

\author{
BESCHREVEN EN TOEGELICHT \\ DOOR
}

S. W. TROM P.

Wanneer men de Kapoeas-rivier, die aan de Westkust van Borneo in zee valt, ruim 400 Engelsche mijlen opstoomt, hetgeen men bij gemiddelden waterstand met een vaartuig van zes à zeven voet diepgang doen kan, komt men aan den rechter zijtak, de Mĕndalam, waaraan enkele mijlen boven de uitmonding de groote Dajaksche kampong Tandjoeng-Karang ligt.

Deze bestaat hoofdzakelijk uit ééne woning (lamin), zes meter boven den grond gebouwd, circa 350 meter lang, bevattende 92 kamers en bewoond door 1163 mannen, 202 vrouwen, 95 jongens en 93 meisjes, alle 559 behoorende tot den stam der Kajan-Dajaks. De Mĕndalam-Kajans zijn evenals hunne naamgenooten van de Mahakam (Koetei) een onderdeel van den hoofdstam, die ten Noorden van de Batang-Loepars van Batang-Rĕdjang op Sĕrawak's grondgebied gevestigd is en gerekend moet worden tot de Centrale Dajaks.

$Z_{i j}$ zijn niet geheel onbekend, want reeds Veth heeft in zijn "Borneo's Wester-afdeeling" eenige bladzijden 2 aan hen gewijd. $\mathrm{Z}_{\mathrm{ij}}$ hebben zich steeds doen kennen als gewillige, ijverige, flinke menschen, met wie het Bestuur gaarne te doen had en op wie het ook konde staat maken. Reeds sedert vele jaren komt het koppensnellen niet meer bij hen voor; 't is althans niet bekend, dat zij zich daaraan nog schuldig maken.

Hoewel zij in beschaving nog niet zóó hoog staan, dat zij bepaalde goden aanbidden, zoodat van godsdienst bij hen ook geen sprake kan zijn, verheffen zij zich toch reeds verre boven het

1 Zielentelling gehouden in Mei 1888.

' Deel II blz. 373 en vv. 
laagste peil. Zij zijn tot dien trap gevorderd, waarop zij, zonder zich in de herkomst daarvan te verdiepen, het bestaan van bovennatuurlijke, zoowel goede als kwade, wezens aannemen, die vele menschelijke neigingen en eigenschappen bezitten, echter meer macht hebben dan de menschen en daardoor het lot van dezen beheerschen. De kwade geesten stellen zij zich voor als naijverig op de menschen, tuk op het aanbrengen van ongeluk, eene voorstelling, die in hooge mate influenceert op des Dajaks doen en laten.

Bepaalde vereering van goede geesten komt bij hen niet voor; van eene voorvaderlijke eeredienst zijn, voor zoo verre ik weet, ook geen sporen meer aanwezig; alleen worden de goede geesten menigvuldig te hulp geroepen in den strijd tegen de booze geesten, overtuigd als de Dajak is, dat die boozen wijken, waar de goeden optreden.

In vele opzichten zijn de Mĕndalam-Kajans nog behoudend; men ziet dit o. a. aan hunne kleeding, hunne leefwijze; maar het lijdt geen twijfel of meer en meer zal hierin door de aanraking met vreemdelingen verandering komen en zullen door Maleischen, alias Mohamedaanschen invloed zoowel sociale toestanden als godsdienstige begrippen gewijzigd worden. Reeds is veel veranderd; zoo ziet men, om nog eens op de kleeding terug te komen, reeds enkelen, die de tjantjoet (schaamgordel) verwisseld hebben tegen een Chineeschen broek; bij het dansen omwikkelen de vrouwen het vroeger bloote bovenlijf met kostbare sarongs; de ityphallische beelden vóór de huizen bestaan niet meer; men snelt niet meer; de geesten verliezen aan macht en aanzien.

Dit alles zal nog erger worden, ja, de tijd zal wel niet meer ver af zijn, dat van de vroegere oorspronkelijkheid geen spoor meer te vinden is. Daarom zijn feesten, zooals ik er één bijwoonde, van belang en verdienen zij eene beschrijving. Wel worden die niet meer gevierd met al den luister van weleer en toonen zij niet meer den ruwen Dajak van die dagen, maar zij herinneren toch aan het verleden, door dat zij van oude zeden en gewoonten de afdruksels zijn. Deze, schoon verflauwd, zijn nu nog herkenbaar; eerlang echter dreigt zulks verloren te gaan.

Toen wij den 9 Mei 1888 in de kampong Tandjoeng-Karang kwamen, waren aldaar juist weinige dagen te voren de hoofden Sĕnggiang en Igau met een groot aantal volgelingen van Serrawak teruggekeerd, waarheen zij, volgens hun eigen verklaring, gegaan waren om zich met daar aanwezige Dajaksche stammen te verzoenen en te trachten de in vrijheidstelling te bewerken van de Pĕnhings en Kajans, die 
in 1885 aan de Mahakam geroofd en sedert in Serrawak in slavernij gebleven waren.

Wegens den behouden terugkeer na eene afwezigheid van meer dan zes maanden verkeerden Sĕnggiang en Igau met de hunnen in een toestand van "pantang" en moesten zij gaan "ajau".

Hoewel de beteekenis van deze woorden bekend is, wil ik toch bij beiden een oogenblik stilstaan en mijne beschouwingen omtrent het verband daartusschen alsmede omtrent dat tusschen oorzaak en gevolg hier ten beste geven. Wij hebben daarbij voor oogen te houden, hetgeen straks omtrent het geloof des Dajaks werd opgeteekend, speciaal wat betreft het gevaar, waardoor hij zich ten allen tijde bedreigd acht van de zijde der booze geesten. Dit gevaar toch verlaat hem nooit; in elke periode van zijn leven hangt het hem boven het hoofd, zoowel in die, welke met zijn geboorte begint als in de daaropvolgende, die met het omhangen van een kralen halsketen een aanvang neemt, als in die, welke hij met zijne meerderjarigheid of met zijn huwelijk intreedt. Maar bovendien zijn er perioden, waarin hij zich buitengewoon bedreigd acht, namelijk wanneer hem eenig bijzonder geluk is overkomen. Dit nu was het geval met Sĕnggiang, Igau en de hunnen; zij waren gezond en wel van een verre reis teruggekeerd, aan de gevaren van berg- en bosch- en watergeesten, van menschen en dieren ontkomen; wat natuurlijker dan dat de booze geesten op hen naijverig waren en hen bedreigden.

Van het standpunt van den Dajak met zijn geloof, als werd aangegeven, is het begrijpelijk, hoe hij het gevaar van een bezoeking van den booze, zich openbarende in rampen (brand, misoogst) of nog duidelijker in ziekten, vooral, wanneer deze door den dood eindigen, wenscht te voorkomen en, liever dan te trotseeren, tracht afteweren. Ook is het te begrijpen, dat hij als middel hiertoe een menschenoffer bezigt. Hiermee toch kan de offeraar beoogen of het binden van een geest, opdat deze den bedreigde tot schutsgeest 1 diene, of het geven van een plaatsvervanger 2 om den booze hiermee tevreden te stellen, en hoewel niet uitgemaakt kan worden, welk doel een offeraar zich oorspronkelijk in omstandigheden als van Sĕnggiang, Igau c. s. gesteld heeft, de Dajak zelf, steeds machinaal de oude gewoonten volgende, het allerminst het doel van zijn offer kan preciseeren, is toch in allen gevalle het feit van de offerande verklaarbaar.

1 Wilken, "Iets over de schedelvereering bij de volken van den Indischen Archipel", Bijdragen tot de T. L. en Vk. v. Ned. Ind. 5e volgreeks dl. IV, bl. 99.

2 t. a. p., bl. 116 . 
Meestal zal, geloof ik, wel het verkrijgen van schutsgeesten het idee bij een menschenoffer geweest zijn; althans zijn de koppen, die men in grooten getale in Dajaksche huizen vindt opgehangen, als beschermende fetisen te beschouwen, daar zij te eten krijgen, zooals een ieder kan zien o. a. aan de eieren, bij die schedels op stokjes gestoken. Herbergden die koppen geen schutsgeesten, men zou ze evenmin te eten geven als de koppen, bij de graven geplaatst, waarvan de geesten de ziel van een afgestorvene vergezellen, dus afwezig zijn. Ook zou men hen dan niet een tijdlang in eere houden, zooals thans geschiedt; wel verzorgt men hen op den duur niet, maar dit is toe te schrijven aan het denkbeeld, dat ieder zijn eigen schutsgeest moet hebben en dat die der ouders niet meer kan dienen voor de kinderen; van dár die behoefte aan steeds nieuwe koppen, waarbij de oude afgedaan hebben. Dezen zullen echter niet wederom in eigen kampong voor een ander doel gebruikt worden; inzonderheid zal geen oude kop bij een graf geplaatst worden, hetgeen zoude neerkomen op het verlagen van een ouden schutsgeest tot dienaar van den geest eens afgestorvenen; zelfs waar het symbool alleen nog van de werkelijkheid is overgebleven, wordt hierop gelet en eindigt men den rouwtijd niet met ceremoniën bij een schedel, uit eigen woning afkomstig, maar wel bij een, elders verkregen.

Wij spraken tot nu toe over het doel van een menschenoffer, in zooverre dit betrekking had op het te behandelen onderwerp; thans moeten wij nog even stilstaan bij de wijze, waarop het gebracht werd. Naar ik vermoed, werd oorspronkelijk bij de Dajaks het menschenoffer gebracht door het zoogenaamde "toelooi", zijude het dooden van een mensch, dien men in zijn macht had, een krijgsgevangene, een eigen of een gekochten slaaf. Zoo'n offer heette "djaoem".

Het "toelooi" komt nu nog een enkelen keer in het geheim voor, zoowel aan de Boven-Mĕlawi als aan de Boven-Kapoeas, maar vroeger was het, zooals mij meermalen meegedeeld werd, algemeen, vooral bij die gelegenheden, welke steeds bovenal een menschenoffer hebben vereischt, in de eerste plaats bij begrafenissen. Dit is ook nog niet zoo lang geleden, want personen van een 40 jaar oud herinneren zich zeer goed, hoe het geschiedde. Zoo vertelde ons een hoofd van de Taman-Dajaks, een stam, die nabij de Mĕndalam-Kajans aan de Boven-Kapoeas woont, hoe hij meermalen van zoo'n "toelooi"-feest na een sterfgeval getuige was geweest en gezien had hoe de "djaoem", stevig gebonden, door mannen op de offerplaats werd rondgeleid, terwijl de vrouwelijke nabestaanden van den afgestorvene het offer 
met kleine messen en pieken verwondden, het intusschen vriendelijk toesprekende en opdragende om toch vooral goed de ziel van dien afgestorvene te dienen en te verzorgen, hiermee voortgaande tot de "djaoem" bijna den geest gaf, waarop de mannelijke betrekkingen met hunne kapmessen een einde maakten aan die marteling 1.

Natuurlijk had het "toelooi" groote bezwaren, daar het niet onder het bereik van elkeen was; niet ieder toch had slaven of was bemiddeld genoeg dezen te koopen.

Daar bovendien dit oflermateriaal schaarscher moet zijn geworden, laat het zich begrijpen, dat men het op andere en wel minder kostbare wijze gezocht heeft, waartoe "ajau" (koppensnellen) het aangewezen middel was. In geval toch dat men een vervanger voor zich zelf wilde stellen, moest men redeneeren dat de onbelichaamde booze geest geen behoefte had aan een belichaamd maar wel aan een onbelichaamd mensch nl. aan een menschelijke ziel, dat de offeraar dus niet een geheel menschelijk lichaam, waarvan het transporteeren ook veelal te bezwarend zou zijn geweest, strikt noodig had doch alleen dat gedeelte, waar de ziel huisvestte, zijnde het hoofd. Dit ook had men noodig, waar een schutsgeest verlangd werd of wel een dienende geest voor een afgestorvene. Hoofden nu, konden betrekkelijk gemakkelijk bij andere stammen buit gemaakt worden; van dár dat het "ajau" langzamerhand bijna geheel in de plaats getreden is van het "toelooi".

Verklaart het bovenstaande, waarom Sĕnggiang, Igau c. s. moesten gaan "ajau ", wij moeten thans onze aandacht vestigen op het woord "pantang".

Pantang (Mal.) $=$ pĕmali, (Modangsch) $=$ njoewin (Bahausch) is zoowel te vertalen door: "verboden" als door: "in een toestand verkeeren, waarin op iemand of iets verbodsbepalingen rusten".

Zoo is een rijstveld bij de Bahau-Dajaks "pantang", wanneer een hert daarover geloopen heeft en mag dientengevolge niet betreden worden.

Bij de Toendjoeng-Dajaks wilde ik een hoofd bezoeken, maar hij was ziek en onder behandeling van "bělians"; zijn huis en erf waren door dezen "pantang" verklaard en op straffe des doods was het aan vreemdelingen verboden, die verbodsbepalingen te overtreden door binnen te gaan.

De "pantang" voor personen komt bij de Dajaks in hoofdzaak

${ }^{1}$ Op de Oostkust van Borneo kwam het een paar jaar geleden nog voor, dat Dajaks te Berouw en Boeloengan kwamen om slaven te koopen ten einde dezen na een sterfgeval op het graf van een afgestorvene te dooden. 
neer op onthouding (die wij als vasten kennen) van hetgeen aangenaam is, zooals: het dragen van versierselen (oorringen, colliers, enz.) en van goede kleeren, het eten van goede vischsoorten, van varkensvleesch, van rijst (aardvruchten zijn inferieur voedsel, voldoende om het leven te rekken maar meer niet; rijst is lekker, dus eenigszins weelde), de coïtus, het rooken van tabak, het betelkauwen, het vasthouden van wapens (dit laatste kan zijn grond vinden in het bij de Dajaks heerschende begrip, dat het hanteeren van wapens eervol, dus aangenaam is; het kan echter ook een gevolg zijn van het begrip, dat ijzer op het doen en laten van geesten influenceert).

Omtrent het doel van het vasten zegt Spencer in zijne "Principles of Sociology" 1: "Involuntary as abstinence from food often is with the primitive man, and causing as it then does vivid dreams, it becomes a deliberately-adopted method of obtaining interviews with the spirits" en later "But besides fastings thns originating, thare is the tasting which results from making excessive provision for the dead. By implication this grows into an accepted mark of reverence; and finally becomes a religious act."

Het vasten van de Dajaks, bestaande in eene onthouding van hetgeen aangenaam is, heeft, dunkt mij, een anderen grondslag en heeft meer bepaaldelijk ten doel: het opwekken van* medelijden, het toonen van deemoed. Vasten is op zich zelf ook geen religieuse of pieuse daad maar vergezelt die, gaat daaraan vooraf. De pieuse daad zelf is het menschenoffer en, hetzij dat dit gebracht wordt om een schutsgeest te erlangen, dan wel om een vervanger te geven of om een afgestorvene te bevredigen, steeds is de grondoorzaak vrees; vrees van den mensch, die door zijn offer hoopt te ontsnappen aan de macht van den sterkeren boozen geest, 't zij dezen met het offer bevredigende, 't zij tegen dezen een steun krijgende in een schutsgeest. En waar nu een mensch een daad volvoert, voortkomende uit vrees in zóón'n groot gevaar, daar ligt het in den aard der zaak, dat hij zich het succes van die daad tracht te verzekeren door deemoed, door medelijden op te wekken. Medelijden opwekken toch moet de menschen reeds zijn ingeboren, want wij merken het bij de dieren op; slaat maar een hond in oogenblikken van groot gevaar gade; men zal zien, dat het dier het gevaar met betrekking tot eigen moed en eigen krachten taxeert; valt die taxatie uit ten voordeele dezer

1 Deel I, blz. 261. 